\title{
Sequencing and phylogenetic analysis of partial CXCR2 gene of Murrah buffalo
}

\author{
S. A. Wani ${ }^{1}$, M. L. Sangwan ${ }^{2}$, M. A. Dar ${ }^{3}$, A. Kumar ${ }^{2}$, M. A. Rafee ${ }^{4}$ and D. Baro ${ }^{2}$ \\ 1. Division of Animal Biotechnology, Indian Veterinary Research Institute, Izatnagar - 243122, Uttar Pradesh, India; \\ 2. Department of Animal Biotechnology, Lala Lajpat Rai University of Veterinary and Animal Science, Hisar, Haryana, \\ India; 3. Department of Veterinary Physiology and Biochemistry, Karnataka Veterinary, Animal and Fisheries Sciences \\ University, Hebbel, Bangalore, Karnataka, India; 4. Division of Veterinary Surgery and Radiology, Indian Veterinary \\ Research Institute, Izatnagar - 243122, Uttar Pradesh, India \\ Corresponding author: S. A. Wani, email: wanisajad759@gmail.com
}

Received: 22-02-2014, Revised: 07-04-2014, Accepted: 16-04-2014, Published online: 22-05-2014

doi: $10.14202 /$ vetworld.2014.342-346

How to cite this article: Wani SA, Sangwan ML, Dar MA, Kumar A, Rafee MA and Baro D (2014) Sequencing and phylogenetic analysis of partial CXCR2 gene of Murrah buffalo, Veterinary World 7(5): 342-346.

\begin{abstract}
Aim: Present study was carried out to sequence and phylogenetic analysis of $C X C R 2$ gene of Murrah buffalo.

Materials and Methods: For the present investigation, from a group of forty eight Murrah buffaloes (Bubalus bubalis), blood samples were collected randomly from eight animals, out of which four were healthy and four were mastitic.

Results: The amplification of Interleukin- $8 B(I L-8 B)$ receptor gene target sequence was carried out using the primer pair in an optimized polymerase chain reaction. Partial sequencing of $I L-8 B$ receptor gene of Bubalus bubalis (Murrah) has been done successfully. The sequences of $I L-8 B$ receptor gene showed $99 \%$ homology to that of Bos indicus $\times$ Bos taurus, $98 \%$ to that of Bos taurus, $97 \%$ to that of Ovis aries, $93 \%$ to that of Sus scrofa, $92 \%$ to that of Equus caballus and $90 \%$ to that of Felis catus.

Conclusion: From the present study it can be concluded that the PCR amplification procedure for target region of $I L-8 B$ receptor gene yielding 459 bp products has been standardized, which yielded consistent and specific amplification. Amplification of partial $I L-8 B$ receptor gene (exon $2-459 \mathrm{bp}$ ) using self designed primers specific for cattle ortholog sequence signifies that the locus is conserved in cattle and buffaloes. In phylogenetic tree, the target sequence of $I L-8 B$ receptor gene of Bubalus bubalis were found to be more closely related to Bos indicus $\times$ Bos Taurus and Bos taurus than to Ovis aries and Sus scrofa.
\end{abstract}

Keywords: $C X C R 2$ gene, Murrah buffalo, phylogenetic analysis.

\section{Introduction}

Mastitis, an inflammatory reaction of mammary gland is the most dreaded disease for dairy farmers because of reduced milk production, increased treatment costs, labour, milk discarding following treatment, death and premature culling [1]. As resistance to mastitis is a polygenic trait, genes associated with neutrophil function are candidate genes for mastitis resistance. Neutrophils are the predominant cell type found in the mammary tissue/secretions during early inflammation and constitute more than $90 \%$ of the total leukocytes [2]. Several candidate pathways were also found in the study on integrated genomic data from genome-wide association mapping in cattle, and transcriptomic data from microarray studies on mastitis pathogens. Of great interest are $I L-17$ and $I L-8$ signaling pathways [3]. Interleukin- $8(I L-8)$ is the main chemo- attractant in this process and binds on two receptors, namely $I L-8$ RA (CXCR1) and IL-8 RB (CXCR2) present on neutrophils. $I L-8 B$ receptor is essential for neutrophil migration to the mammary gland and infection resolution. $C X C R 2$ binds to $I L-8$ and oncogene $\alpha$, neutrophil activating peptide-2. Earlier it was given the

Copyright: The authors. This article is an open access article licensed under the terms of the Creative Commons Attribution License (http://creativecommons.org/licenses/by/2.0) which permits unrestricted use, distribution and reproduction in any medium, provided the work is properly cited. name CDw128b, but now it is changed to CD182. Chemokine receptors are $\mathrm{G}$ protein-coupled receptors containing 7 transmembrane domains that are found on the surface of leukocytes [4]. The CXCR1 and CXCR2 genes encoding receptors lay on the second chromosome approximately $20 \mathrm{~kb}$ separated from each other and on opposite strands. The gene located more centromeric encodes for $C X C R 1$, the gene located more telomeric encodes for $C X C R 2$ [5]. Activation of CXCR1 is believed to result in a wider array of antimicrobial processes than activation of $C X C R 2$, but $C X C R 2$ might respond to a lower concentration of ligand [6]. The CXCR2 gene in bovines is $7.5 \mathrm{~kb}$ in size consisting of two exons of $83 \mathrm{bp}$ and $1089 \mathrm{bp}$ separated by an intronic sequence length of $6328 \mathrm{bp}$. It gives a transcript length of $1172 \mathrm{bp}$ and translation length of 363 amino acids [7]. Bovine IL-8 receptor loci (CXCRl and $C X C R 2$ ) have been mapped approximately 90.3 $\mathrm{cM}$ from the centromere of bovine chromosome (BTA)2. The chemotactic cytokine belong to the chemokine superfamily which can be divided into four families (CXC, $\mathrm{CX} 3 \mathrm{C}, \mathrm{CC}$ and $\mathrm{C}$ ) according to the position of the first two closely paired and highly conserved cysteines near the amino terminus of the protein [8]. The two N-terminal cysteine of CXC chemokines ( $\alpha$-chemokines) are separated by one amino acid, represented in this name with an "X". 
There have been 17 different $\mathrm{CXC}$ chemokines described in mammals. CXC chemokine can be further classified into ELR-positive and ELR-negative molecule based on the presence or absence of a specific amino acid motif of glutamic acid -leucine-arginine (ELR for short) immediately before the first cysteine ELR-positive CXC chemokines specifically induce the migration of neutrophils, and interact with chemokine receptors $C X C R 1$ and $C X C R 2$. An example of an ELRpositive CXC chemokine is interleukin-8, which induces neutrophils to leave the bloodstream and enter into the surrounding tissue [9]. $C X C R 2$ binds with CXCL8 (IL-8) with high affinity, in addition to IL8, it also binds with different CXC ELR + chemokines, including $C X C L 1$ (GRO- $\alpha$ ), CXCL2 (GRO- $\beta$ ), $C X C L 3$ (GRO- $\gamma$ ), CXCL5 (epithelial cell-derived neutrophilactivating peptide-78), and $C X C L 7$ [10].

$I L-8$ is the most extensively studied chemokine to date. Other CXC chemokines that lack the ELR motif, such as CXCL13, tend to be chemoattractant for lymphocytes [11]. Intracellular signaling by chemokine receptors is dependent on neighbouring G-proteins. Gproteins exist as a heterotrimer and they are composed of three distinct subunits $(\alpha, \beta$ and $\gamma)$. When the molecule GDP is bound to the G-protein subunit, the Gprotein is in an inactive state. Following binding of the chemokine ligand, chemokine receptors associate with G-proteins, allowing the exchange of GDP for another molecule called GTP, and the dissociation of the different $G$ protein subunits. The subunit called G $\beta$ activates an enzyme known as Phospholipase C (PLC) that is associated with the cell membrane. PLC cleaves Phosphatidylinositol $(4,5)$-bisphosphate (PIP2) to form two second messenger molecules called inosital triphosphate (IP3) and diacylglycerol (DAG). DAG activates another enzyme called protein kinase $\mathrm{C}$ (PKC), and IP3 triggers the release of calcium from intracellular stores. These events promote many signalling cascades, affecting a cellular response. CXCL8 (IL-8) binds to its specific receptors, $C X C R 1$ or $C X C R 2$, a rise in intracellular calcium activates the enzyme phospholipase D (PLD) that goes on to initiate an intracellular signaling cascade called the MAP kinase pathway. At the same time the G-protein subunit $\mathrm{G} \alpha$ directly activates an enzyme called protein tyrosine kinase (PTK), which phosphorylates serine and threonine residues in the tail of the chemokine receptor, causing its desensitisation or inactivation. The initiated MAP kinase pathway activates specific cellular mechanisms involved in chemotaxis, degranulation, release of superoxide anions, and changes in the avidity of cell adhesion molecules called integrins. Like many other chemoattractants, $I L$ 8 induces re-arrangement of the cytoskeleton, changes in intracellular $\mathrm{Ca}++$ levels, activation of integrins, exocytosis of granule proteins, and respiratory burst $[12,13]$.

Therefore, the present study was carried out to sequence and phylogenetic analysis of $C X C R 2$ gene of Murrah buffalo.

\section{Materials and Methods}

Ethical approval: Approval for collecting blood samples was granted by Institutional Animal Ethics Committee.

Climatic Condition and Experimental Animals: Geographically, Hisar Haryana is located at $29.09^{\circ} \mathrm{N}$ $75.43^{\circ} \mathrm{E}$ in western Haryana, at an altitude of 215 above mean sea level. Hisar has a continental climate, with very hot summers and relatively cool winters. Summer season goes up to $46^{\circ} \mathrm{C}$ while winter goes down up to $1.5^{\circ} \mathrm{C}$. For the present investigation, blood samples were collected from forty eight unrelated Murrah buffaloes (Bubalus bubalis) from Government Livestock Farm, Hisar. Approximately $10 \mathrm{ml}$ of venous blood sample was collected randomly from eight animals in $15 \mathrm{ml}$ sterile polypropylene centrifuge tube containing $0.5 \mathrm{ml}$ of $0.5 \mathrm{M}$ EDTA as anticoagulant. Genomic DNA was isolated from blood samples as described by Sambrook and Russel method with minor modifications. The quality of genomic DNA was determined by agarose gel electrophoresis on $0.7 \%$ w/v agarose. The purity of DNA was evaluated by taking the ratio of optical densities (OD) at $260 \mathrm{~nm}$ to that of $280 \mathrm{~nm}$, by spectrophotometer (Biorad Smart SpecTM Plus). The samples having OD ratio between 1.7-1.9 were considered having acceptable purity and used in future experiments.

Partial exon 2 of $I L-8 B$ gene was amplified by using the self-designed primers using FAST PCR software. Forward 5'..GACTCTGCCCCAT GTC GG .3'Reverse5'..GATGGCCCTGCGGAAGATG..'3. The reaction mixture for PCR was prepared in $0.2 \mathrm{ml}$ thin walled PCR tubes. The master mix was prepared by adding $16.7 \mu \mathrm{l}$ of nuclease free water (NFW), $2.5 \mu \mathrm{l}$ of Dream Taq ${ }^{\mathrm{TM}}$ DNA polymerase buffer, $0.5 \mu \mathrm{l}(100 \mu \mathrm{M})$ dNTPs, $1.0 \mu \mathrm{l}$ of each primers $(20 \mu \mathrm{M}), 0.3 \mu \mathrm{l}$ of DreamTaq ${ }^{\mathrm{TM}}$ DNA polymerase (Fermentas) and for each sample and after proper mixing it was distributed to all the tubes $(22 \mu \mathrm{l}$ to each tube). $3 \mu \mathrm{l}$ of genomic DNA (50 ng) was added in all the tubes. All these steps were carried out on wet ice. The $25 \mu 1$ reaction mix was kept for amplification in programmed thermocycler (Bio-Rad i-Cycler) with initial denaturation at $95^{\circ} \mathrm{C}$ for $5 \mathrm{~min}$, then 35 cycles of denaturation at $95^{\circ} \mathrm{C}$ for 30 seconds (s), annealing at $64^{\circ} \mathrm{C}$ for $30 \mathrm{~s}$ and extension at $72^{\circ} \mathrm{C}$ for $1 \mathrm{~min}$, the cycles were followed by a final extension at $72^{\circ} \mathrm{C}$ for $10 \mathrm{~min}$. Amplification products were resolved by gel electrophoresis on $1.5 \%$ agarose gel in TAE buffer, stained with ethidium bromide (1 $\mu \mathrm{g} / \mathrm{ml})$. 50bp ladder was used as molecular weight marker. PCR products were visualized by UV- transilluminator and photographed. PCR products were purified using QIAquick gel extraction kit (QIAGEN) to remove primer dimers and other PCR ingredients, before custom sequencing. Sequencing was done by using automated DNA sequencer Applied Biosystem 3130 XL Genetic Analyzer at Department of Animal Biotechnology, College of Veterinary Sciences, Lala Lajpat Rai University of Veterinary and Animal Science, Hisar, Haryana, India. The vector specific 
Available at www.veterinaryworld.org/Vol.7/May-2014/14.pdf

Table-1: Identity of $I L-8 B$ receptor gene (target region) of Bubalus bubalis with other Species

\begin{tabular}{|c|c|c|c|}
\hline Accession number & IL-8B receptor gene of specific species & Query coverage (\%) & Identity (\%) \\
\hline JF927834.1 & Bos indicus $\times$ Bos taurus & 98 & 99 \\
\hline JF927835.1 & Bos indicus x Bos taurus & 98 & 98 \\
\hline DQ328664.1 & Bos taurus & 98 & 98 \\
\hline XM004005420.1 & Ovis aries & 98 & 97 \\
\hline AK230995.1 & Sus scrofa & 98 & 93 \\
\hline XM003365149.1 & Equus caballus & 99 & 92 \\
\hline XM003991133.1 & Felis cattus & 99 & 90 \\
\hline
\end{tabular}

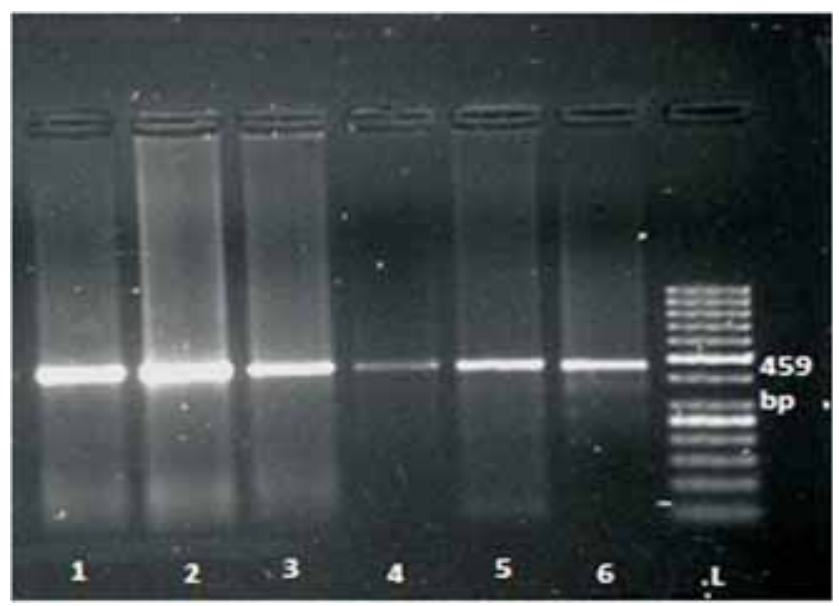

Figure-1: PCR amplification of CXCR2 gene Lane L: 50 bp ladder, Lane 1 to 6: PCR product of CXCR2 gene (459 bp)

primer (Pjet1.2 Forward/ Pjet1.2 Reverse) were used for sequencing by BigDye ${ }^{\circledR}$ Terminator v 3.1Cycle Sequencing Kit (ABI). The reaction mixture for PCR was prepared in $0.2 \mathrm{ml}$ thin walled PCR tubes. The master mix was prepared by adding $1.9 \mu 1$ of nuclease free water (NFW), $2.0 \mu$ l of Dilution Buffer (5x), $0.6 \mu 1$ DMSO as distributed to all the tubes $(5.0 \mu 1$ to each tube). Then added $2 \mu 1$ of pJET1.2 Forward/Reverse sequencing primers $(4 \mu \mathrm{M})$ in each tube. Then $3 \mu$ of plasmid was added in all the tubes. All these steps were carried out at $4^{\circ} \mathrm{C}$. The $10 \mu 1$ reaction mix was kept for amplification in programmable thermocycler (BioRad i-Cycler) with initial denaturation at $96^{\circ} \mathrm{C}$ for 1 min then 25 cycles of denaturation at $96^{\circ} \mathrm{C}$ for 10 seconds (s), annealing at $50^{\circ} \mathrm{C}$ for $5 \mathrm{~s}$ and primer extension at $60^{\circ} \mathrm{C}$ for $4 \mathrm{~min}$. After the final extension step, the PCR products were purified by BigDye Terminator v3.1Clean up (Tube Method). The sequences obtained from automated DNA sequencer were analyzed using NCBI BLASTn online software tool available on internet after converting sequences into FASTA format. ClustalW2 programme was used for multiple sequence alignment of buffalo $I L-8 B$ receptor gene sequence with other species DNA sequences retrieved from NCBI database. The phylogenetic tree was also constructed using MEGA4 software to show relatedness among the species with respect to $I L-8 B$ receptor gene fragment.

\section{Results and Discussion}

The amplification of $I L-8 B$ receptor gene target sequence was carried out using the primer pair in an optimized PCR. The molecular size of the PCR products was estimated to be 459 bp by comparing with DNA size markers (Figure-1). The sequence data generated after sequencing was compared with the sequences available in NCBI database and the maximum homology search was done using BLASTn. The sequences of $I L-8 B$ receptor gene showed $99 \%$ homology to that of Bos indicus $\times$ Bos taurus , $98 \%$ to that of Bos taurus, $97 \%$ to that of Ovis aries, $93 \%$ to that of Sus scrofa, $92 \%$ to that of Equus caballus and $90 \%$ to that of Felis cattus (Table-1). Shivanand et al. studied PCR-SSCP and sequencing of a 269 bp fragment of $C X C R 2$ receptor gene in Vrindavani cattle [14]. However no information is available about sequencing of bubaline CXCR2 gene. Bovine homologs were identified to six human $C X C R$ receptors $(C X C R 1-6)$ by bioinformatic analyses of available bovine sequences and genome databases [15]. Multiple sequence alignment of partial $I L-8 B$ receptor gene sequence of Bubalus bubalis was carried out among other species to study sequence based diversity globally. The alignment was carried out using ClustalW2 and Bioedit software. The alignment revealed highest similarity to Bos indicus $\times$ Bos taurus (Figure-2). The phylogenetic tree was constructed using MEGA4 software [16] to show relatedness between the species with respect to $I L-8 B$ receptor gene fragment (Figure-3). In phylogenetic tree, sequences of target region of $I L-8 B$ receptor gene of Bubalus bubalis are found more closely related to Bos indicus $\times$ Bos taurus than Bos taurus, Ovis aries and Sus scrofa. Equus caballus and Felis catus are the farthest species. The chemokine receptors are thought to have originated from a single ancestral gene with 
Query aequence Equa caballus Felia catus Bos taurus ovis aries sus scrofa

Query sequence Equa caballus Pelia catus Bos taurus Oria arte Sus acrofa

Query sequence Equo caballua Felia catus Bos taurus Ovis ariog sua acrofa

Query sequence Equa caballus Fel1a catus Bos taurus Ovia arien sus acrofa

Query sequence Equa caballus Pel1a catus Bos taurus Sug scrofa

Query Bequence Equa caballus Pelia catus Bos taurus Ovis aries Sua acrofa

Query sequence Equa caballua Pelis catus Bos taurus Ovis axies Sus acrofa

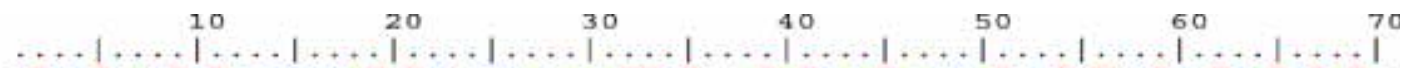

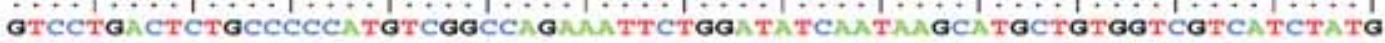
TACCGGACTCGGCCCC ATGCCGGCCNGANACTCTGGNNTGNACACATATGCCCTGGTCGTCATCTACG TGTCAGACTCTGCCCC ATGCAGGCCAGNATCTCTGGNANTCAATCAGTATGCCATGGTGGTCATCTATG

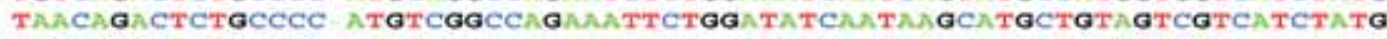
TACCAGACTCTGCCCC ATGTCGGCCAGAATCTCTGGATATCAATAAGCATGCTGTGGTCATCATCTATG

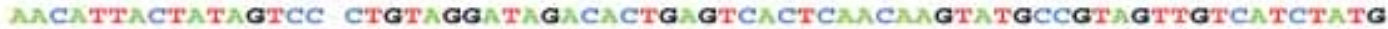 80 90 100 110 120 130 140 $\ldots|\ldots| \ldots|\ldots| \ldots|\ldots| \ldots|\ldots| \ldots|\ldots| \ldots|\ldots| \ldots|\ldots| \ldots|\ldots| \ldots|\ldots|$

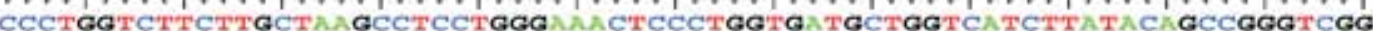
CCCTGGTCTTCCTGCTGAGCCTGCTGGGANATCCCTGGTGNTCTGGTCGTCTTATACACCCGGGTCAG

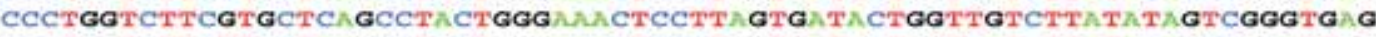
CССTGGTCTTCTTGTAAGCCTCCTGGGNACTCCCTGGTGNTGCTGGTCATCTTATACAGCCGGNTGG CTCTGGTCTTCTTGCTAAGCCTCCTGGGNACTCCCTGGTGNTGCTGGTCATCTTGTACAGCCGGGTCGG

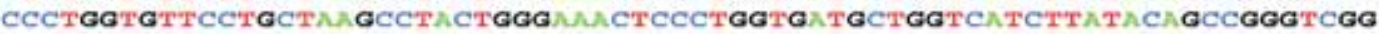

150

160

170

180

190

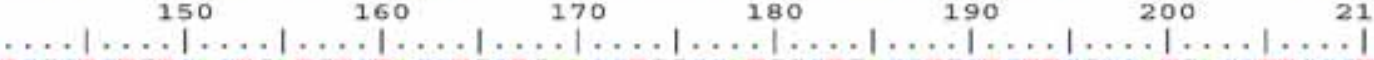

210 CCGCTCTGTCACTGATGTCTACCTGCTGANCTGGCCATGGCTGNCCTGCTCTTCGCCATGXCCTTGCCT

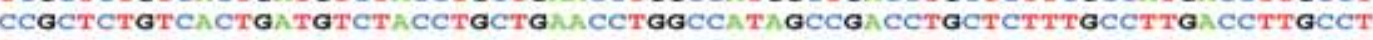

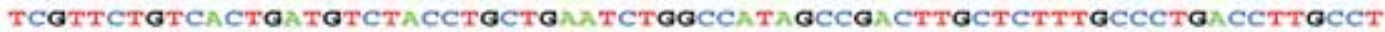
TCGCTCTGTCACTGATGTCTACCTGCTGACCTGGCCA TGGCTGACCTGCTCTTCGCCATGACCTTGCCT TCGCTCCGTCA CTG TGTCTACCTGCTGA CCTGGCONTGGCTGACCTGCTCTTCGCCATGNCCTTGCCT

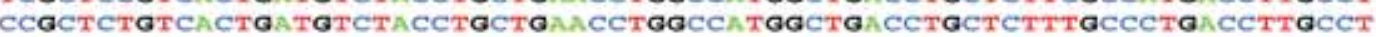
220
230
240
250
260
270
$2 B C$

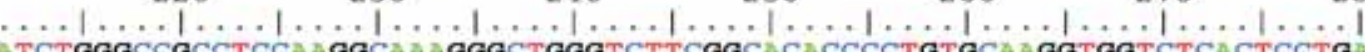
TCTGGGCCGCCTCCANGGCANAGGCTGGGTCTTCGGCACACCCCTGTGCAAGGTGTCTCACTCCTG:

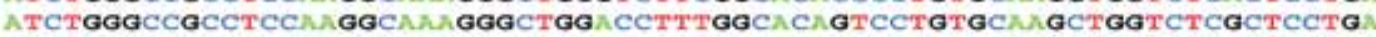
ATCTGGGCTGCCTCCANGGCANAGGCTGG TCT'TGGCACAGCCCT'TGCAAGGTGGTCTCGCTCCTGN ATCTGGGCCGCCTCCAAGGCAAAGGCTGG TCTTCGGCACACCCCTGTGCA GGTGGTCTCACTCCTG

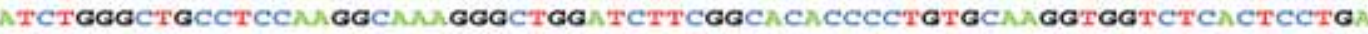
ATCTGGGCCACCTCCNAGGCANAGGGCTGG

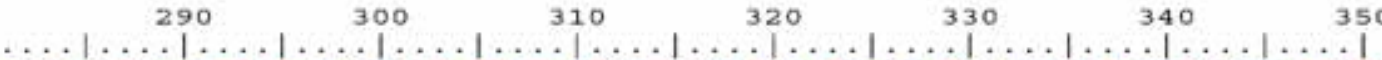

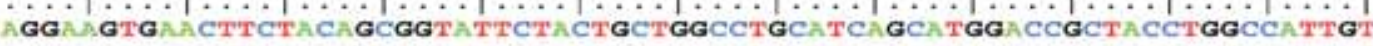

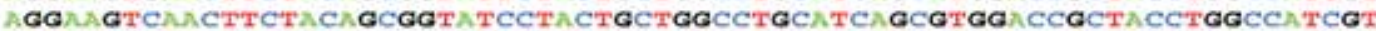
AAGAATCAACTTCTACA GCAGCATCCTGCTGCTGGCCTGCATCAGCGTGGACCGCTATTTGGCCATTGT AGARGTGACTTCTACAGCGGTATTCTACTGCTGGCCTGCATCA GCATGGACCGCTACCTGGCCATTGI

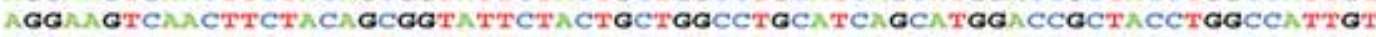
AGGNATCAACTTCTACAGTGGTXTTCTACTGCTGGCTTGCATCAGCGTGGACCGCTACCTAGCCATCGI

$$
\begin{array}{llllll}
360 & 370 & 380 & 390 & 400 & 410
\end{array}
$$

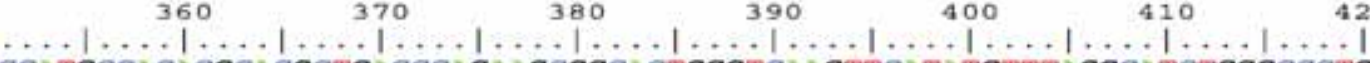

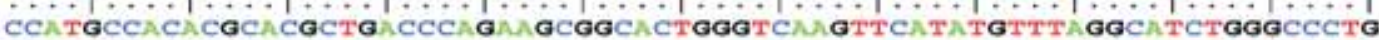
CCACGCCNCNCGCACACTGACCCAGA GCGGCACTGGGTCA GTTCATATGCTTGGGCATCTGG TCCTG CCATGCCACACGCACACTGACTCAGNAGCGGCACTGGGTCNAGTTCATATGCTTAGGCATCTGGGCCCTG CCNTGCCACACGCHCGCTGNCCCAGNGCGGCACTGGGTCNATTCATATGTTTAGCATCTGGGCCCTG CСАTGCCACACGCACACTGACCCAGAACGGCACTGGGTCNIGTTCATATGTTTAGGCATCTGGGCCCTG CCACGCCACACGCTCGCTGACCCAGAAGGCCACTGGGTCANGTTCATATGCACAGGCATCTGGGCCCTG

440

450

460

$\ldots|\ldots| \ldots|\ldots| \ldots|\ldots| \ldots|\ldots| \ldots|\ldots| \ldots \mid \ldots$

TCCGTG TCCTGGCCСTGCCCGTCTTCATCTTCCGCA GGGCCATCAT TCCTTCATCCTGGCCCTGCCCGTCTTCCTCTTCCGAAAGGCCATCT: TCCCTG TCOTGTCCCTGCCCNTCTTCATCTTCCGCA GGGCCNTCT

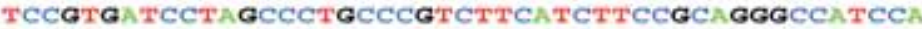
TCCGTGATCCTGGCCCTGCCCNTCTTCNTCTTCCGCNGGGCCNTCC

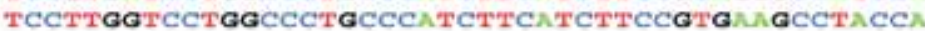

Figure-2: Multiple sequence alignment of $C X C R 2$ gene with different species.
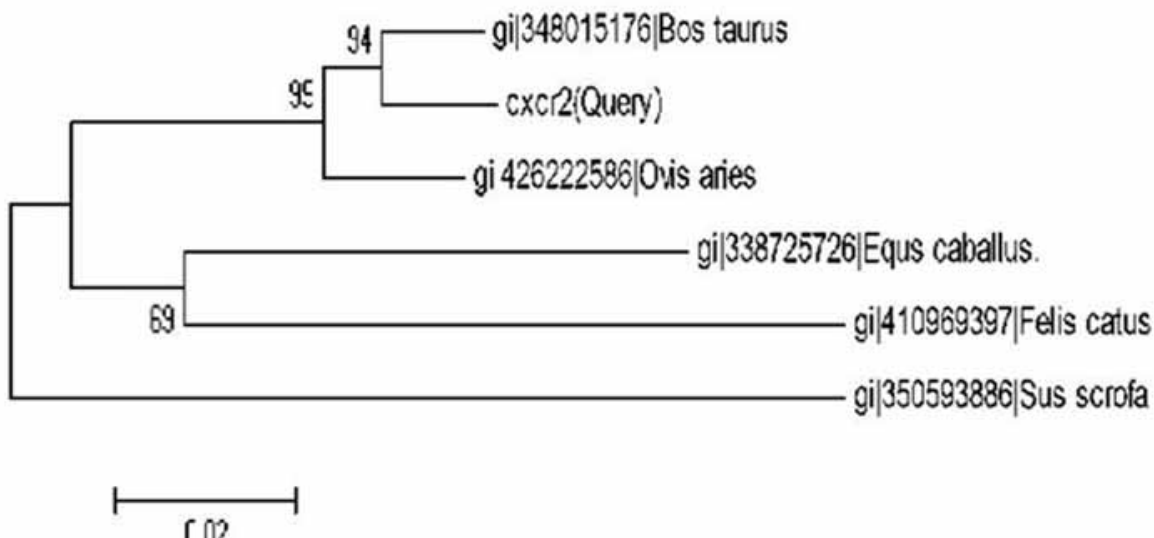

Figure-3: Phylogenetic tree of $C X C R 2$ gene region depicting the evolutionary relationship among different species. 
individual genes arising due to subsequent gene duplication events [17]. Many of the chemokine receptors are clustered across the genome and these proximal chemokine receptors also tend to be closely related. Generally the chemokine receptor family is well conserved between mammalian species, as can be seen by a comparison of the well-studied human and murine chemokine receptor genes; however some differences do exist, indicating ongoing evolution of the chemokine receptor system.

\section{Conclusion}

From the present study it can be concluded that the PCR amplification procedure for target region of $I L-8 B$ receptor gene yielding $459 \mathrm{bp}$ products has been standardized, which yielded consistent and specific amplification. Amplification of partial $I L-8 B$ receptor gene (exon 2- $459 \mathrm{bp}$ ) using self designed primers specific for cattle ortholog sequence signifies that the locus is conserved in cattle and buffaloes. Partial sequencing of IL-8B receptor gene of Bubalus bubalis (Murrah) has been done successfully. Basic Local Alignment Search Tool (BLAST) analysis revealed sequence identity of target region (IL- $8 B$ receptor gene) of Murrah buffalo with, $99 \%$ with Bos indicus $\times$ Bos taurus (JF927834.1), 98\% with Bos taurus (DQ 328664.1), 97\% with Ovis aries (XM004005420.1) and $93 \%$ with Sus scrofa (AK230995.1). In phylogenetic tree, the target sequence of $I L-8 B$ receptor gene of Bubalus bubalis are found more closely related to Bos indicus $\times$ Bos Taurus and Bos taurus than to Ovis aries and Sus scrofa. Molecular characterisation and phylogenetic studies of $C X C R 2$ gene can serve as guide for polymorphism and association studies with mastitis resistance for marker assisted selection breeding programme. Further this study can be used to identify cytokine markers which can be used to develop anti mastitis vaccines.

\section{Authors' contributions}

SAW planned and carried out research work under his MVSc thesis programme in collaboration with advisory members and guide MLS. MAD, AK, MAR and DB played a helping hand role in carrying of experiment and computational analysis of data. All authors read the manuscript and approved the final manuscript.

\section{Acknowledgements}

The authors are thankful to Vice Chancellor, Lala Lajpat Rai University of Veterinary and Animal Sciences, Hisar, Haryana for providing facilities during thesis research work of SAW. The authors are also thankful to The Department of Biotechnology, Government of India for providing Fellowship (as a source of fund) throughout the Masters study.

\section{Competing interests}

The authors declare that they have no competing interests.

\section{References}

1. Yang FL, Li XS, Yang BZ, Zhang Y, Zhang XF, Qin GS and Liang XW. (2012) Clinical mastitis from calving to next conception negatively affected reproductive performance of dairy cows in Nanning, China. Afr. J. Biotechnol., 11(10): 2574-2580.

2. Abera M, B Demie, K Aragaw, F Regassa and A Regassa, (2010) Isolation and identification of Staphylococcus aureus from bovine mastitic milk and their drug resistance patterns in Adama Town, Ethiopia. J. Vet Med Anim Health, 2:29-34.

3. Lewanowska, Sabat A.M., Gunther, J., Seyfert H.M. and Olsaker I. (2012) Combining quantitative trait loci and heterogeneous microarray data analyses reveals putative candidate pathways affecting mastitis in cattle. Anim. Genet., 43: 793-799.

4. Murdoch, C. and Finn, A. (2000) Chemokine receptors and the role in inflammation and infectious disease $J$. Am. Soc. Hemat., 95 (10): 3032-3043.

5. Rambeaud, M., Clift, R. and Pighetti, G.M. (2006) Differential calcium signaling in dairy cows with specific CXCR1 genotypes potentially related to interleukin 8 receptor functionality. Immunogenetics. 59: 53-58.

6. Stillie, R., Farooq, S. M., Gordon, J. R. and Stadnyk, A. W. (2009) The functional significance behind expressing two IL8 receptor types on PMN.J.Leukoc. Biol., 86: 529-543.

7. Ensembl database, URL: $<$ http://www.ensembl.org $>$. Accessed on 15-05-2013.

8. Murphy, P. M., Baggiolini, M., Charo, I. F., Hebert, C. A., Horuk, R., Matsushima, K. and Miller, L.H. (2000). International union of pharmacology. XXII. Nomenclature for chemokine receptors. Pharmacol Rev. 52: 145-176.

9. Walz, A., Kunkel, S. L. and Strieter, R. M. (1996) CXC chemokines- an overview in: Chemokines in disease Koch A.E., Streiter, R.M. Landes: Austin. p1-26.

10. Ahuja, S. K. and Murphy, P. M. (1996) The CXC chemokine growth- regulated oncogene (GRO) alpha, GRO beta, GRO gamma, neutrophil-activating peptide- 2 and epithelial cell derived neutrophil activating peptide-78 are potent agonist for the type B, but not the type A, human interleukin-8 receptor. J. Biol. Chem., 271:20545-20550.

11. Heaton, M. P., William W., Laegreid, Craig W., Beattie, Timothy P. L., Smith, S. and Kappes, M. (1999) Identification and genetic mapping of bovine chemokine genes expressed in epithelial cells. Mamm. Genome. 10 (1): 296-297.

12. Detmers, P. A., Powell, D. D., Walz, A., Clark-Lewis, I., Baggionlini, M. and Cohn, Z. A. (1991) Differential effects of neutrophil-activating peptide / IL-8 and its homologues on leukocyte adhesion and phagocytosis. J. Immunol., 147: 4211-4217.

13. Paccaud JP, Schifferli JA, Baggiolini M (1990). NAP-1/IL-8 induces up-regulation of CR1 receptors in human neutrophil leukocytes. Biochem Biophys Res Commun, 166: 187-92.

14. Shivanand, D. M., Ahlawat, S. P. S., Bhushan, B., Tiwari, A.K., Sonawane, A., Kumar, P., Inamdar, B. and Dutt,T. (2011) PCR-SSCP and sequencing of CXCR2 receptor gene in virindavani cattle. J. Adv. Vet. Res., 1:52-56.

15. Stephanie, W., Nazneen, Victoria, E., Freya, L., George, A., Dirk, W., Michael, W. and Tracey, J. (2010) The bovine chemokine receptors and their mRNA abundance in mononuclear phagocytes. BMC Genomics, 11:439.

16. Tamura, K., Dudley, J., NeI, M. and Kumar, S. (2007) MEGA4: Molecular Evolutionary Genetics Analysis (MEGA) Software Version 4.0. Mol. Biol. Evol. 24(8): 1596-1599.

17. Fredriksson, R., Lagerstrom, M.C., Lundin, L.G. and Schioth, H.B. (2003) The G-protein-coupled receptors in the human genome form five main families. Phylogenetic analysis, paralogon groups, and fingerprints. Mol Pharmacol, 63:1256-1272. 